\title{
CLASSIFICATION AND CHARACTERISTIC OF SOILS IN URBAN AREAS (ON THE EXAMPLE OF ODESSA CITY)
}

\author{
Anastasiya Khokhryakova \\ Chief Soil Engineer \\ Odessa Branch of the State Institution «Soil Protection Institute of Ukraine» \\ 19 Laboratorna str., Limanka village, Ovidiopol dist., Odessa reg., Ukraine, 65037 \\ tarleva.a.i@gmail.com
}

\begin{abstract}
The purpose of the research:

1) establishment of classification and diagnostic characteristics of soils under different functional using of the city territory;

2) parameterization of the structure, composition and properties of anthropogenically transformed and anthropogenically created soils;

3) development of a classification scheme, taking into account its use in cadastral and economic grouping.

General scientific (systematic, analysis, synthesis, generalization, statistics) and traditional (soil-genetic, profile-morphological, laboratory-analytical and cartographic) research methods were used to study the genetic characteristics of soils of Odessa and their classification.

The ecological-profile-genetic classification of soils of urban areas, which combines profile-genetic and factor-ecological approaches, is proposed. Within the city there are natural, anthropogenically transformed and anthropogenically created soils. Soils during cadastral and economic grouping are united into two groups of transformed and technological soils of human settlements and other territories with anthropogenically transformed soil cover, are distinguished. According to cadastral and economic grouping, within Odessa the area of transformed soils is 11,915.6 ha, technological soils is 1922.5 ha.

The proposed scheme of soil classification of urban areas includes 2 supertype levels, 3 types and 13 subtypes of soils, which are divided according to their genetic profile and combined according to the characteristics of natural and anthropogenic factors of soil formation. For urban cadastre, organization, planning and implementation of land management, economic activity, a scheme of supplementing the list of agricultural soils of Ukraine with cadastral and economic grouping of soils of urban areas was proposed. The grouping of soils includes two associations:

1) transformed;

2) technological (artificially created) soils - a total of 14 cadastral and economic groups.

Keywords: soils of urban areas, urban soil classification, Odessa city, urbanozem, technological soils, economic and functional zoning of the city.
\end{abstract}

DOI: $10.21303 / 2504-5695.2020 .001404$

\section{Introduction}

Within human settlements components of the external natural environment undergo an anthropogenic influence, manifested in the transformation of almost all its main features and quality parameters. Contamination of atmospheric air by emissions of enterprises, disturbance and contamination of the soil cover, dangerous geological processes (shifts, subsidence and so on) are most spread, but not just all results of human activity. Soils in the city ecosystem are the base of human activity, spatial ground for placing buildings and constructions, sorbent and retainer of harmful substances, nutrition source of plants, regulator of the atmospheric air composition. A human influence on soils is reflected on a condition of the external environment as a whole. So, it is very important that state management in the sphere of soil resources must be based on principles of sustainable development, being concentrated on the activity, directed on preservation, reproduction of fertility and quality of soils within human settlements. Specialists of academic, scientific, designing and production institutions and organizations need a distinct classification scheme of such soils, methodical and diagnostic principles of their study, proper normative support of regulation of soils protection in the sphere of city planning.

The classification problematics belongs to most difficult sections of soil studies, is one of most discussion because of differences in principles, taken as a base of classifications of world soils. The question of comfort, genetic and universal type of the soil classification is priority, being 
connected with a necessity to give actual information about soils to different spheres of human activity. The process of renovation, generalization and addition of existent classification schemes, taking into account urban soils is inevitable. It is connected with continuous accumulation of information about the soil cover of human settlements, its properties, spatial placement and features of transformation under the anthropogenic load influence.

\section{Literary review}

A series of works of Ukrainian and world scientists is devoted to the problem of soils of urbanized areas. In relatively short terms there is accumulated an enough amount of information about main properties of soils of urbanized areas and revealed their concrete differences from natural soils:

- formation on poured, wave-built, mixed soils and cultural layer [1];

- presence of inclusions of building and everyday rubbish in upper horizons;

- growth of the profile up at the expanse of continuous introduction of different materials and intensive eolian sputtering;

- change of the acid-alkaline balance with a tendency to alkalization [2], development of processes such as salinization as a result of technological introduction of salt-containing substances [3];

- high contamination by heavy metals, oil products, emission components of industrial enterprises [4];

- change of physical-mechanical properties of soils (lowered moisture capacity, increased density, stony character and so on) [5].

Main directions of studies of urban soils are:

- question of systematization, classification and diagnostics [6, 7];

- study of morphological, physical-chemical properties [8];

- study of the ecological condition of soils in cities, industrial and auto transport influence at the level of heavy metal contamination $[9,10]$;

- study of microbiological peculiarities and biological activity of soils of cities, use of biotesting methods at studying city soils $[11,12]$;

- peculiarities of mapping, prognostication of changes of city soils using GIS-technologies $[13,14]$.

In classifications of soils of different countries of the world specific urban soils either not separated at all or their definition is possible only at highest taxonomic levels. In the soil classification of the USA Soil Taxonomy anthropogenic soils are in same sections with natural ones [15]. Soil scientists of Great Britain separated a certain group of soils in their classification - man-made soils [16]. Polish scientists separate three main categories of urban soils: mechanically transformed; friable layers that cover the natural surface; chemically transformed soils [17]. In Germany soil scientists proposed the new taxonomic unit - urbic anthrosols - substrates, created as a result of anthropogenic activity. Much attention in this classification also paid to soils with the cut high layer (denusols) and to ones, soaked with oil-petrol liquids and gazes near gas stations and car parks [18]. In Slovak cities such soil groups are separated: natural soils; ones, subject to a human influence (so-called "culturezems"); artificial soils, created by humans (so-called "anthrozems") [19]. The classification of anthropogenically transformed soils and soil-like surface formations, entering in the general classification of Russian soils, is based on peculiarities of the profile-genetic construction of a soil profile and also on the type of soil-forming beds [16].

In Ukraine the problem of classification of urban soils remains unsolved even despite rather big number of classification schemes [20,21]. The genetic classification of soils of Ukraine [22] is two-sided. From one side, it demonstrates differences and common features of main characteristics of soils depending on soil formation factors, from the other one - genetic connections between soils. The classification scheme includes the class "Anthropogenic soils", group of types "Technological soils" (technozems and lithozems). The genetic ecological-substantive classification on the parametric base [20] details the content of each taxonomic level according to the natural diversity of soils, it separates recultivated soils (reculturezems) togeth- 
er with natural types of soils [23]. The ecological-biogeochemical classification of Ukrainian soils [21] includes sections of natural-anthropogenic and technological soils. An attempt was made [24] to add this classification by soils of urban territories, taking into account peculiarities of the steppe zone of Ukraine. Today groups of transformed (artificially created) soils of human settlements and other territories with anthropogenically transformed soil cover are not included in the nomenclature list of agroproduction soils, approved by the conduction Order of the State agrarian cadastre [25].

\section{Research aim and tasks}

The main research aim is:

1) to establish classification-diagnostic signs of soils under conditions of different functional use of a territory;

2) parametrization of the construction, composition and properties of anthropogenically transformed and athropogenically created (technological) soils;

3) to elaborate a classification scheme, taking into account its use at cadastral and economic (functional) grouping.

It is provided to realize the following main tasks for attaining the set aim:

- to establish genetic-morphological peculiarities of soils of Odessa city depending on natural factors and functional use of a territory, to determine main chemical and physical-chemical properties of city soils, to establish functioning peculiarities of elementary soil processes under conditions of urban environment;

- to generalize existent classification schemes of soils of urbanized territories and to develop an ecologic-profile-genetic classification of soils of urbanized territories, taking into account its use at the cadastral and economic (functional) grouping. To develop the cadastral and economic grouping of soils of urbanized territories.

\section{Materials and research methods}

At studying genetic peculiarities of city Odessa soils and their classification there were used general scientific research methods (system, analysis, synthesis, generalization, statistics) and traditional ones (comparative-geographic, comparative-analytic, profile-morphological and cartographic). The laboratory analytic works were conducted by the conventional methods of soils analysis: SSU ISO 11465-2001 [26], SSU 4730:2007 [27], SSU 4289:2004 [28], SS 26951-86 [29], SSU 8347:2015 [30], SSU 4114-2002 [31], SSU 8346:2015 [32], SSU ISO 10390:2007 [33], SS 26487-85 [34], SSU 7912:2015 [35], SSU 7943:2015 [36], SSU 7908:2015 [37], SSU 7909:2015 [38], SSU 7944:2015 [39], SSU 7945:2015 [40]. The cartographic materials were formed using ArcGIS 10.2.2 geoinformation package.

\section{Research results of the soil cover of Odessa city}

Odessa city is situated within the seaside-estuary physical-geographic district of the DnestrBugh steppe region of the Black sea forest accumulative lowlands. Zonal soils of the Southern steppe subzone in the Dnestr-Bugh district of the accumulative forest plain are southern chernozems, mainly weak-humus hard-loamy (agroproduction soil group 71e).

At the preparatory stage key plots were made by the complex analysis of diverse initial materials (cartographic, literary, fund). The territories reflect the diversity of city soils, taking into account functional zoning of the city (industrial zones, parks and squares, residential zones of oneand multistory buildings in different parts of the city, reserve lands) and position in the system of natural-landscape zoning of the territory.

For studying the system "soil-forming factors - soils", there were made 43 key-plots, at which soils in 70 soil cuts and 24 diggings were studied (the paper describes main subtypes of natural and technological soils in Odessa city). At the field examination of soils, the morphological description was conducted, and soil samples were selected by genetic horizons (Fig. 1).

Based on the elaborated classification [41] of city soils, taking into account the experience $[21,24,42,43]$, there is proposed a classification scheme of soils of urbanized territories by 
modernizing already existed taxonomic structures in the aspect of their correspondence to a possibility of introducing city soils in the classification scheme of Ukrainian ones (1988).

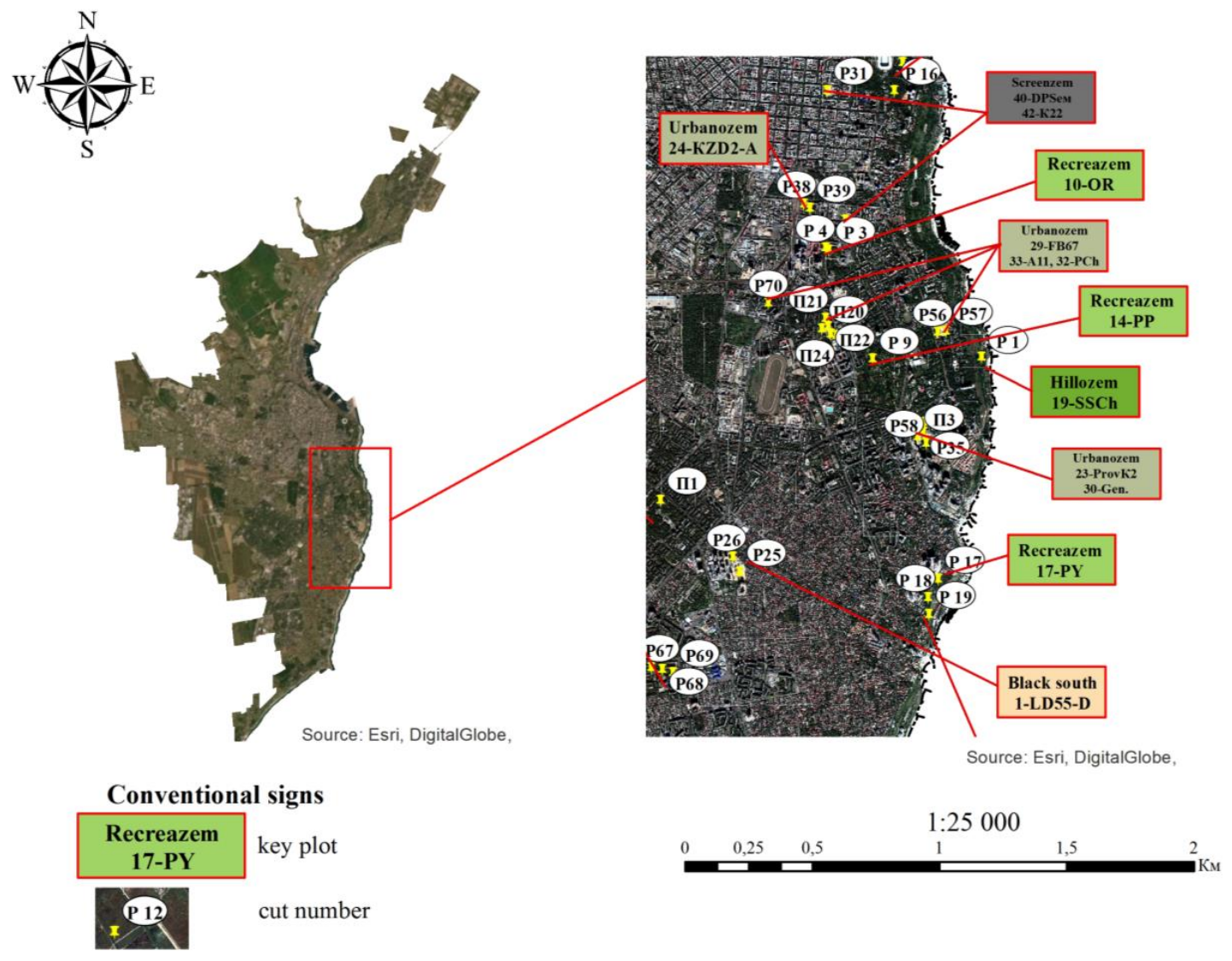

Fig. 1. Placement of main key-plots in Odessa city

The proposed classification of soils of urbanized territories is based on the profile-genetic and factor-ecological approaches. Its ground is morphological features, properties and also conditions of the natural and technological environment that soils of human settlements function, develop and transform in. The proposed classification includes the same taxonomic units, used at classifying natural soils, adapted to ones of urbanized territories. The classification is developed for supporting the city building cadastre. Soils of urbanized territories relate to the class "Technological soils" that includes two types of soils: anthropogenically transformed and anthropogenically created (technological) ones (Fig. 2).

The group of types "Anthropogenically transformed soils" includes two types of soils: "Urbosoils, argosoils" (technological surface-transformed soils) and "Urbozems" (technological deep-transformed soils). Surface transformed are those that keep diagnostic signs that allow to identify them in the system of the existent classification as bodies of natural origin - chernozems, meadows and so on. Deep-transformed lose zonal profiles completely and are new (artificial) soils by construction.

Technological surface-transformed soils are ones within a human settlement, in which a transformation reaches no more $50 \mathrm{~cm}$ without disturbing the placement order of genetic horizons. They keep diagnostic signs, allowing to identify them in the system of the existent classification as bodies of natural origin - chernozems, meadows and so on. The profile formula looks as: $\mathrm{H}(\mathrm{u})-\mathrm{Hp}(\mathrm{u})-\mathrm{Ph}(\mathrm{k})-\mathrm{Pk}$. A name, according to the nomenclature list of soils, is added with a prefix uro- and agro- (if the low part of the profile is not disturbed): southern urbochenozems, southern agrochernozems and so on. These soils within human settlements occur at homestead plots, cultivated agricultural lands and so on. 


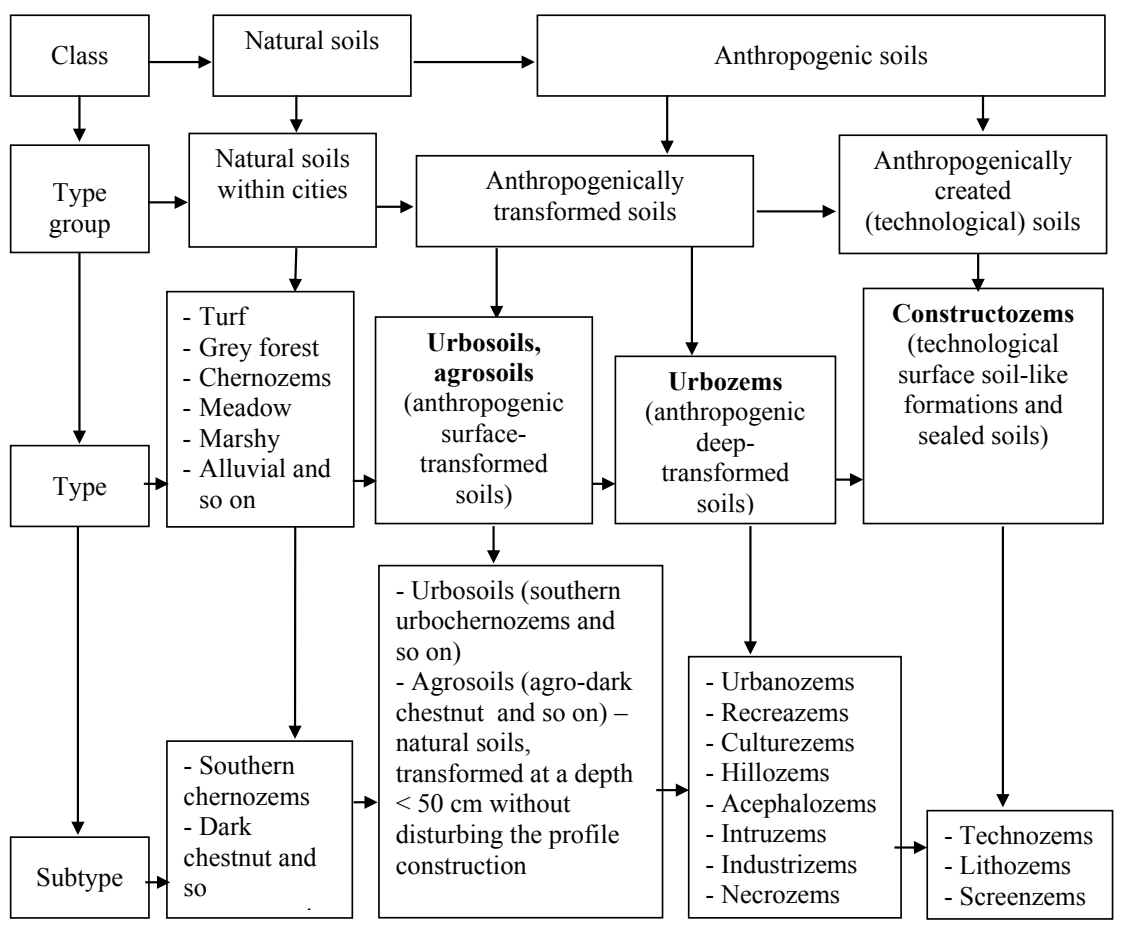

Fig. 2. Scheme of the ecological-profile-genetic classification of soils of urbanized territories (on the example of Odessa city)

Technological deep-transformed soils (urbozems) form at the expanse of urbanization processes, have signs of pedoturbation, physical-mechanical, chemical and so on transformations of the profile in a depth more $50 \mathrm{~cm}$ with elimination of diagnostic horizons, typical to urban soil formation [44].

Urbozems include 9 subtypes of soils:

1) urbanozems (most spread soils of residential zones of a city);

2) recreazems (soils of parks, hydroparks, squares and so on);

3) culturezems (soils of botanical gardens, arboreta and so on);

4) hillozems (artificial or natural soils of coastal hills);

5) acephalozems (form as a result of mechanical removal, replacement, mixing of soil at building and road works);

6) intruzems (soils, formed as a result of oil products penetration at gas stations and along oil pipelines, soakage of fuel-lubricant materials at railways and tracks of rail city transport);

7) industrizems (soils of industrial-municipal territories, contaminated with heavy metals and other toxic substances);

8) necrozems (soils of city cemeteries);

9) dumpzems (soils of dumps within a city, formed spontaneously, not in specially allotted places).

The type "Constructozems" (technological surface soil-like formations and sealed soils) from the group of types "Anthropogenically created (technological) soils" includes three subtypes. The first subtype is technozems - soil-like bodies, purposefully constructed by humans in the process of lands recultivation). The second subtype is lithozems - poured, mixed bodies, sandpit contents, formations of industrial and urbanogenic origin with no analogues in nature, presented by industrial production waste - slag, ashes, slit sediments or hard everyday waste and so on. The third subtype is screenzems - soils, bunch-like bodies, sealed by buildings and constructions, bituminous concrete, paths with a plate cover and so on.

Propositions as to diagnosing soils of human settlements [44] and the proposed ecological-profile-genetic classification became a base for cadastral and economic grouping of these soils. At conducting the cadastral and economic grouping of settlement soils, there were taken into account not 
only morphologic and physical-chemical properties of soil sorts, according to which similarity groups were combined, but also the economic-functional use of a human settlement territory.

For conducting a city planning cadastre, it is important to take into account ecological-functional importance of a territory and also soils, spread in it. Cadastral and economic grouping of soils is based on the complex combination of morphological, agronomic, ecological, economic-functional properties of soil sorts.

It is proposed to add to list of agroproduction groups of soils, stated by Addition 5 of the Regulation by KMU "On statement of the conduction Order of the State land cadastre" of 17 October 2012 [12] the groups of transformed and technological (artificially created) soils of human settlements and other territories with the anthropogenically transformed soil cover.

The group "Transformed soils" at cadastral and economic grouping of human settlement soils combines soil sorts that underwent changes of the morphological construction of the profile under the influence of anthropogenic activity with keeping signs of natural soils (anthropogenic surface-transformed soils). It also combines subtypes, formed as a result of the intensive economic activity (total housing system, industrial building, transport infrastructure) (anthropogenic deep-transformed soils).

The group "Technological (artificially created) soils includes subtypes that reflect purposeful changes of the soil cover by engineer, nature protecting, organizational and other arrangements and sealed soils (technological surface soil-like formations and sealed soils) (Table 1).

Table 1

Cadastral and economic grouping of settlement soils

\begin{tabular}{|c|c|}
\hline Code & Soil group name \\
\hline \multicolumn{2}{|r|}{ Agroproduction soil group } \\
\hline $1-222$ & Names of agroproduction soil groups according to the approved nomenclature list \\
\hline \multicolumn{2}{|c|}{$\begin{array}{l}\text { Groups of transformed and technological (artificially created) soils of human settlements and other territories with } \\
\text { the anthropogenically transformed soil cover }\end{array}$} \\
\hline 223 & Agrosoils (argochernozems, argomeadowzems, agroturf and so on) \\
\hline 224 & Urbosoils (urbochernozems, argomeadowzems, agroturf and so on) \\
\hline 225 & Recreazems \\
\hline 226 & Culturezems \\
\hline 227 & Hillozems \\
\hline 228 & Urbanozems \\
\hline 229 & Acephalozems \\
\hline 230 & Necrozems \\
\hline 231 & Intruzems \\
\hline 232 & Industrizems \\
\hline 233 & Dumpzems \\
\hline 234 & Technozems \\
\hline 235 & Lithozems \\
\hline 236 & Screenzems \\
\hline
\end{tabular}

Natural soils within Odessa city are presented by southern chernozems, spatially placed at territories, free from buildings, lands of agricultural use and at the territory of the international airport and occupy the area 1.2 thousand ha. These territories are located mainly at plain parts of the watershed plateau, a height above sea level varies within 50-60 m. Soil-creating beds are forests. 
Under city conditions southern chernozems develop by the evolution scenario, different from natural conditions. The comparative analysis of morphology of southern chernozems within and beyond the city has revealed that the intensity of the humus horizon of southern chernozems of urbanized territories is by $32 \%$ less compared to the same type soil horizon beyond the city. The profile construction looks as (low limits of genetic horizons are given in brackets, $\mathrm{cm}$ ): H (23.75 \pm 2.06$)$-Hi (43.17 \pm 3.04$)-H p ~(59.44 \pm 4.47)-\mathrm{Ph}(89.29 \pm 3.66)-\mathrm{Pk}(133.69 \pm 5.15)$. Boiling from $10 \%$ solution of saline acid in $90 \%$ of cases is stormy at the surface that is typical for southern carbonate chernozems.

An important diagnostic sign of soils is a differentiation degree of their profile by the granulometric composition. Natural non-disturbed soils of Odessa city (southern chernozems) are mainly characterized by the middle- and hard-loamy granulometric composition in upper humus horizons. The content of physical loam in upper soil horizons varied from 34.52 to $53.49 \%$ (key plot 2-MAO), at that dominant ones are rough-dusty (from 32.02 to $45.45 \%$ ) and slimy (from 16.79 to $29.19 \%$ ) fractions.

According to the analysis of aqueous extracts, southern chernozems have different degree and type of salinization, but mainly salinization processes of natural non-disturbed soils are absent. The weak salinization degree has been revealed in both humus (P43, P49, P64), and in humus-illuvial, upper and low transitional horizons (P43, P45, P60, P61). Chemism is mainly sulphate.

The medium reaction ( $\mathrm{pH}$ value of the soil solution) in the humus horizon of natural non-disturbed soils changes from close to neutral to hard-alkaline ( $\mathrm{pH}$ indices from 7.1 to 8.6). In southern chernozems beyond the city te reaction indices of the soil solution vary within 6.9-7.6 pH units in humus horizons. An increase of $\mathrm{pH}$ indices in soils within the city is connected with the carbonate development, salinization processes, contamination with heavy metals. The sum of absorbed bases $\left(\mathrm{Ca}^{2+}, \mathrm{Mg}^{2+}, \mathrm{Na}^{+}\right)$is $18.07-28.33 \mathrm{mmol} / 100 \mathrm{~g}$ of soil. The content of exchangeable calcium in the soil absorbing complex is from 12.50 to $22.75 \mathrm{mmol} / 100$ of soil, magnesium - from 1.75 to $12.0 \mathrm{mmol} / 100 \mathrm{~g}$ of soil, sodium - from 0.13 to $1.66 \mathrm{mmol} / 100 \mathrm{~g}$ of soil. $\mathrm{Ca}^{2+} \mathrm{mg}^{2+}$ ratio varies from $2: 1$ to $11: 1$ by profile.

In the middle and hard-loamy southern chernnozems (key plot 2-MAO) the humus content in upper horizons varies from 2.42 to $4.05 \%$ and is middle or increased (Fig. 3).

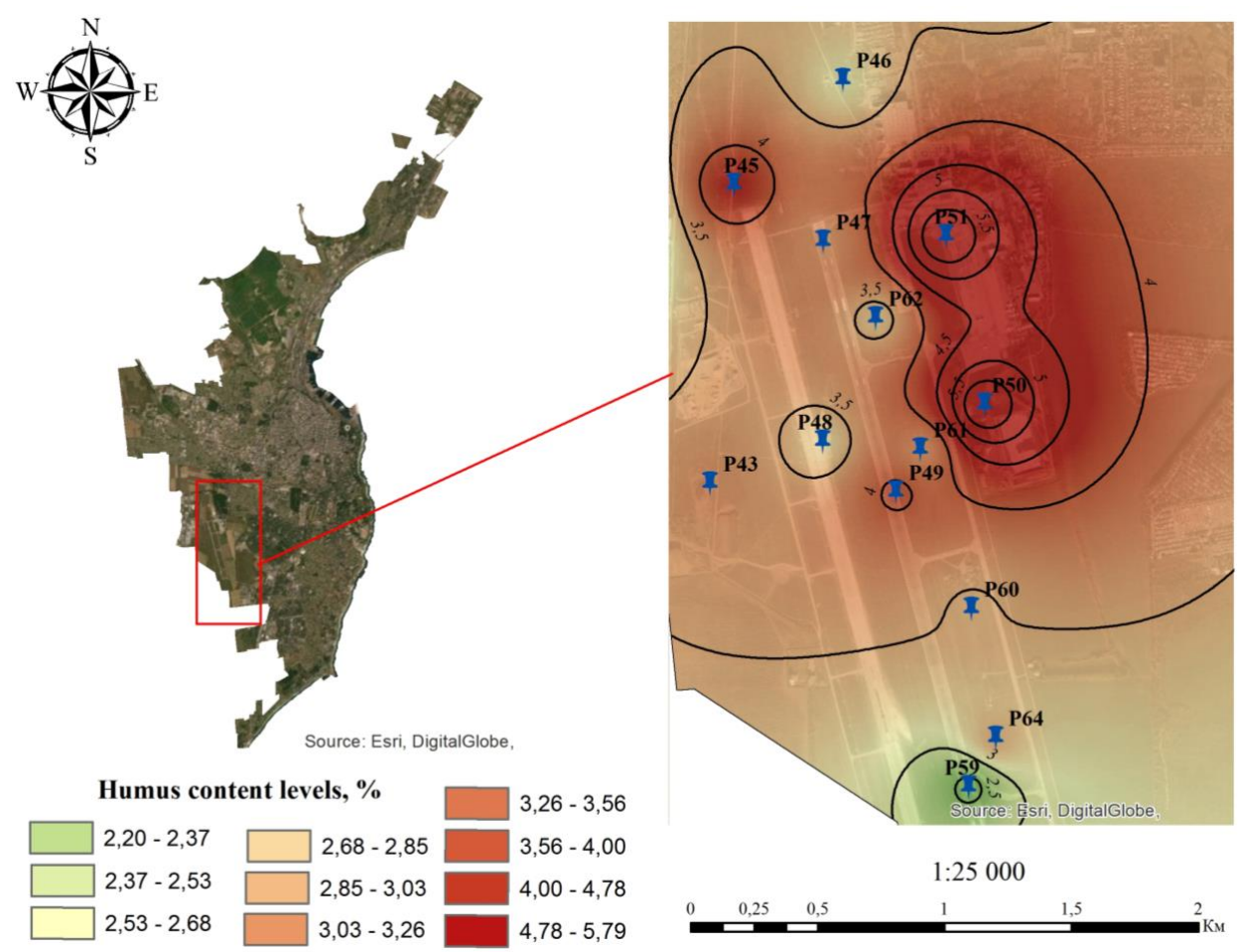

Fig. 3. Spatial distribution of the humus content in southern chernozems of Odessa city 
The content distribution of nutritive substances (nitrogen by nitrification capacity, moving phosphorus and exchangeable potassium) in southern chernozems within the city wi unbalanced. In $80 \%$ of the selected samples very low indices are noted by levels of nitrogen content by nitrification capacity and in $46 \%$ of the samples - by levels of moving phosphorus content: from 0.54 to $3.15 \mathrm{mg} / \mathrm{kg}$ of soil and from 5.91 to $10.93 \mathrm{mg} / \mathrm{kg}$ of soil respectively. In $36 \%$ of the selected samples the content level of exchangeable potassium is increased and high (indices from 215.93 to $358.64 \mathrm{mg} / \mathrm{kg}$ of soil). There is noted the variation coefficient of the content of nitrogen and phosphorus in the humus and humus-illuvial horizon, whereas the potassium content in southern chernozems under city conditions doesn't exceed the content indices of the aforesaid horizons of southern chernozems beyond the city.

Thus, southern chernozems within the city have lower fertility indices than standard southern chernozems by SSU 4362:2004. It is reflected by low indices of the sum of exchangeable cations (in standard soils this value is in diapason $30-42 \mathrm{mmol} / 100 \mathrm{~g}$ of soil), content levels of nitrogen and phosphorus, increased $\mathrm{pH}$ indices (in standard groups the soil solution reaction is neutral and close to neutral).

Anthropogenically transformed soils. Urbanozems are anthopogenic deep-transformed soils, which profile consists of the diagnostic horizon "urbic" U and a series of diagnostic subhorizons. The "urbic" horizon is formed by a dust-humus substrate of different intensity and quality with rubbish admixtures. Urbanozems may lie on impenetrable materials as building and everyday rubbish, fundaments, concrete plates, stones and so on. As genetically independent groups, urbanozems are separated within the residential functional zone of the city (housing system of one or many apartments). The soil area in Odessa city is 7.4 thousand ha (Fig. 4).

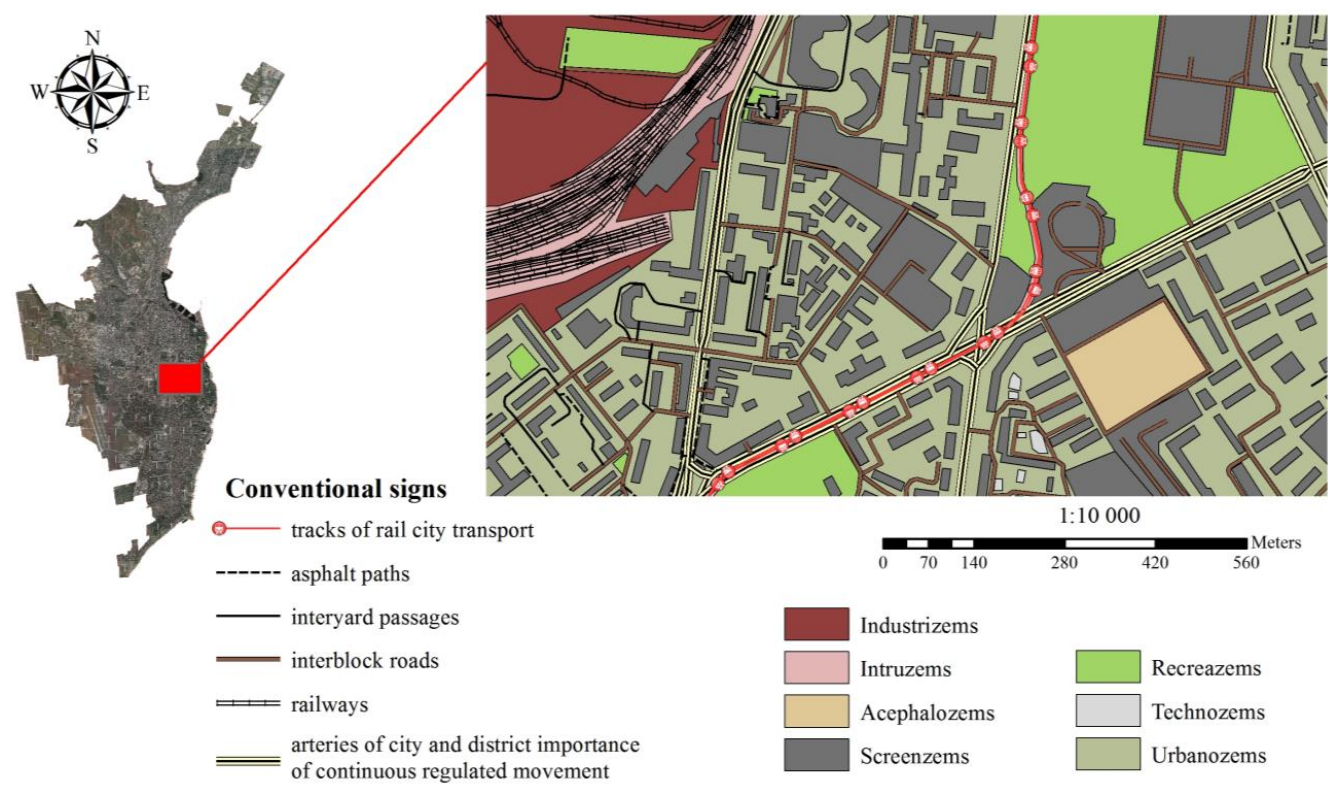

Fig. 4. Map-scheme of spread of anthropogenically transformed soils of Odessa city

Urbanozems form and develop in complex with other anthropogenic deep-transformed soils, creating a mosaic of the soil cover of the city, spread fragments, and their properties greatly depend on type of the functional-economic use of a territory.

The comparative analysis of morphology of urbanozems has revealed that the intensity of horizons essentially changes depending on functional-economic use. The intensity value of the urbic humus horizon has the most variation coefficient, the lower limit is at mark $10-135 \mathrm{~cm}$. The mean arithmetic intensity value of the urbic horizon is $43.36 \pm 7.05 \mathrm{~cm}$. Boiling from $10 \%$ solution of saline acid in $100 \%$ of cases is stormy on the surface that is typical for urbanozems.

The granulometric composition of urbanozems is light- or middle-loamy and directly depends on granulometric composition of substrates, forming the profile of urbanozems. The content 
of physical loam in upper horizons varies from $12.51 \%$ to $44.37 \%$, fine-sandy (from $18.59 \%$ to $34.24 \%$ ) and rough-dusty from $19.45 \%$ to $43.83 \%$ ) fractions are dominant.

For realizing main ecological barrier functions, urbanozems must have optimal parameters. The analysis of statistical data as to content indices of humus in urbanozems testifies to the high distribution variability of an organic substance by the profile, gives a possibility to estimate the quality conditions of soils.

The distribution of content levels of nutritive substances in the humus horizon of urbanozems is not balanced like in natural soils within the city. It is noted, that the indices by content levels of nitrogen by nitrification capacity in $58 \%$ of the selected samples and in $46 \%$ of the samples - by content levels of moving phosphorus and in $71 \%$ of the samples by content levels of exchangeable potassium are very low: from 0.21 to $4.27 \mathrm{mg} \backslash \mathrm{kg}$ of soil, from 3.0 to $10.4 \mathrm{mg} / \mathrm{kg}$ of soil and from 7.49 to $50.0 \mathrm{mg} / \mathrm{kg}$ of soil respectively. $21 \%$ of the samples, selected by nitrogen content indices by nitrification capacity (from 8.8 to $10.92 \mathrm{mg} / \mathrm{kg}$ of soil), and $33 \%$ of the samples, selected by indices of moving phosphorus (from 16.89 to $25.3 \mathrm{mg} / \mathrm{kg}$ of soil) have middle levels of their content. In $13 \%$ of the selected samples the content level of exchangeable potassium is increased (indices from 210.0 to $255.7 \mathrm{mg} / \mathrm{kg}$ of soil).

An organic substance distributes by the profile or urbanozems without any regularity. A variation coefficient of a humus content index in all horizons of the soil profile of urbanozems indicates the essential degree of the urbanization influence. It may be explained by the high complexity of factors, determining processes of humification, nitrification, mineralization and so on, namely by an uneven degree of carbonates, salinization, densification, humidity, contamination, littering of urbanozems. Urbanozems are weak- and little-humus. The humus content in urbanozems, in upper humus horizons varies from low to very high (from 0.86 to $5.40 \%$ ) (Fig. 5).

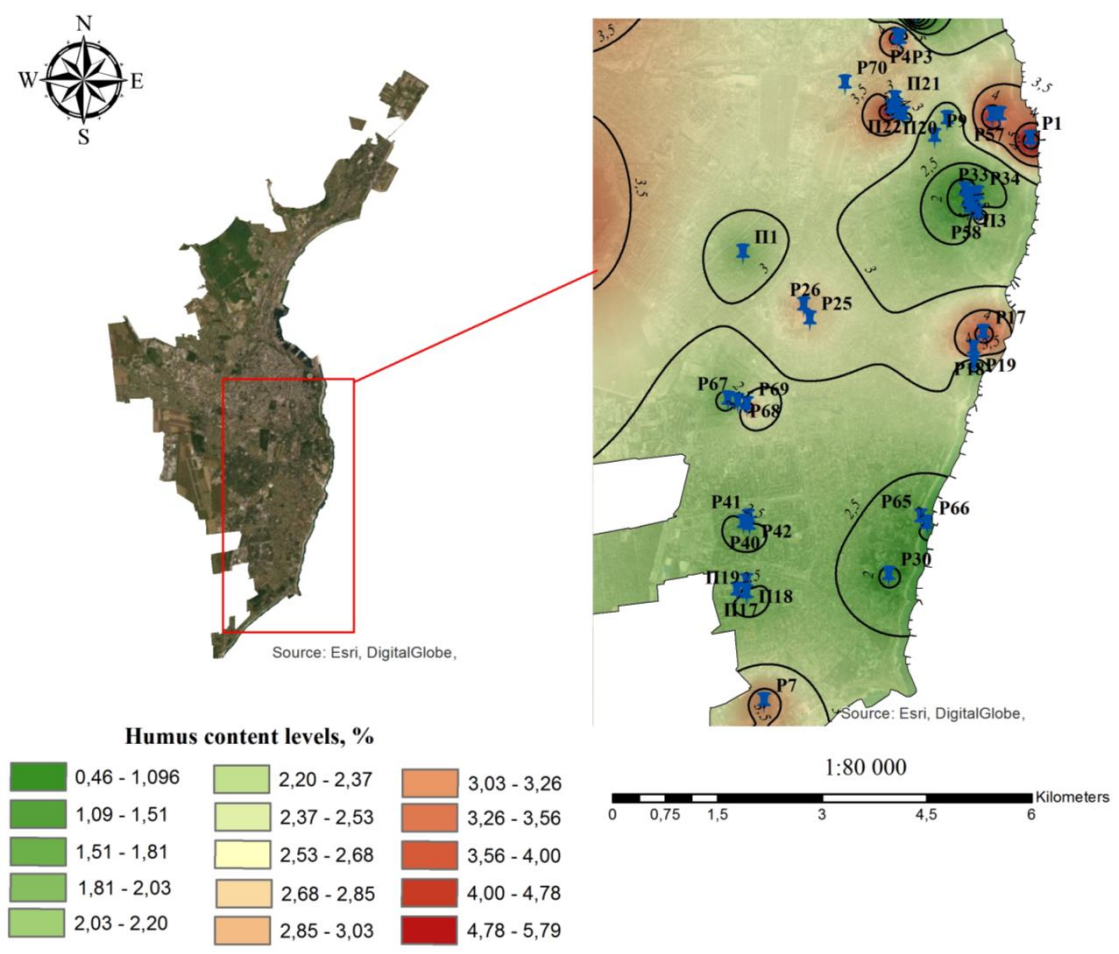

Fig. 5. Spatial distribution of humus in urbanozems

The environment reaction ( $\mathrm{pH}$ value of the soil solution) in the urbic horizon changes from close to neutral to strong alkaline ( $\mathrm{pH}$ indices from 7.1 to 8.7 ), like in southern chernozems within the city. The salinization process in urbic horizons of urbanozems doesn't flow or is weak, but already from a depth more $50 \mathrm{~cm}$ a salinization degree grows somewhere to the strong one and directly depends on composition and properties of substrates, creating a soil. The salinization type 
may be presented by definition frequency using the succession: sulphate - chloride - chloride-sulphate - sulphate-chloride.

The sum of absorbed bases $\left(\mathrm{Ca}^{2+}, \mathrm{Mg}^{2+}, \mathrm{Na}^{+}\right)$in the humus horizon urbic varies from low ( $9.66 \mathrm{mmol} / 100 \mathrm{~g}$ of soil) to high $(24.03 \mathrm{mmol} / 100 \mathrm{~g}$ of soil). The content of exchangeable calcium in the soil absorbing complex is from 5.75 to $17.75 \mathrm{mmol} / 100 \mathrm{~g}$ of soil, magnesium - from 1.00 to $1.00 \mathrm{mmol} / 100 \mathrm{~g}$ of soil, sodium - from 0.21 to $2.17 \mathrm{mmol} / 100 \mathrm{~g}$ of soil. The ratio $\mathrm{Ca}^{2+} \mathrm{mg}^{2+}$ by the profile varies from $2: 1$ to $15: 1$ by profile. Little- and middle-saline urbanozems by salinization degree are separated.

Anthropogenically created (technological) soils. The type "Constructozems" includes three subtypes of artificially created city soils: technozems, lithozems and screenzems.

Technozems (recultivated soils with an organogenic horizon) is soil-like bodies, purposefully constructed by humans, presented by a series of layers with different granulometric compositions and origins and also poured humus layer. A profile of this type of soil-like bodies is constructed by the natural soil model. They have different quality composition, properties and intensity of the organogenic horizon, different properties, composition, disturbance degree of the soil-forming bed. This type of soils forms in districts of industrial and residential house systems, on new lawns, flower-beds, stadiums and so on. The granulometric composition of technozems is middle-loamy, dominating fractions are rough-dusty and slimy. By humus content, technozems are divided in weak-humus (cut P44, П17, П18, П19) and little-humus (P5, Р24). The content of an organic substance in upper humus horizons varies within $0.57 \%$ (cut P44) $5.22 \%$ (cut P24) (Table 2).

Table 2

Characteristics of the composition and properties of technological soils of Odessa city

\begin{tabular}{|c|c|c|c|c|c|c|c|c|c|}
\hline \multirow{2}{*}{$\begin{array}{l}\text { Code of } \\
\text { key plot }\end{array}$} & \multirow{2}{*}{$\begin{array}{l}\text { No. of soil } \\
\text { cut (digging) }\end{array}$} & \multirow{2}{*}{$\begin{array}{c}\text { Name of } \\
\text { genetic horizon }\end{array}$} & \multirow{2}{*}{$\begin{array}{c}\text { Intensity of } \\
\text { genetic horizons, } \mathrm{cm}\end{array}$} & \multirow{2}{*}{$\begin{array}{c}\mathbf{p H} \\
\text { water }\end{array}$} & \multirow{2}{*}{ pH salt } & \multirow{2}{*}{ humus, \% } & \multicolumn{3}{|c|}{$\begin{array}{l}\text { Nutrition elements, } \\
\mathrm{mg} / \mathrm{kg} \text { of soil }\end{array}$} \\
\hline & & & & & & & $\mathrm{N}-\mathrm{NO}_{3}$ & $\mathbf{P}_{2} \mathbf{O}_{5}$ & $\mathbf{K}_{2} \mathbf{O}$ \\
\hline \multirow{3}{*}{$35-\mathrm{TR}$} & \multirow{3}{*}{ P5 } & $\mathrm{TCH}_{1}$ & $0-25$ & 7.1 & 6.9 & 3.09 & 10.12 & 32.82 & 311.76 \\
\hline & & $\mathrm{TCH}_{2}$ & $25-65$ & 7.4 & - & 3.47 & 4.06 & 12.53 & 281.81 \\
\hline & & $\mathrm{TCH}_{3}$ & $65-75$ & 7.1 & - & 3.28 & 1.64 & 9.67 & 450.65 \\
\hline \multirow{2}{*}{ 36-ChMP } & \multirow{2}{*}{$\mathrm{P} 24$} & $\mathrm{TCH}(\mathrm{h})$ & 0-19 & 7.5 & 7.4 & 5.22 & 15.98 & 40.66 & 644.6 \\
\hline & & TCHpk & $19-60$ & 7.8 & 7.7 & 1.16 & \multicolumn{3}{|c|}{ Not studied } \\
\hline \multirow{4}{*}{ 37-S2-Ia } & \multirow{4}{*}{ P44 } & $\mathrm{TCH}_{1}$ & $0-5$ & 8.6 & 7.8 & 0.57 & 0.92 & 8.38 & 298.57 \\
\hline & & $\mathrm{TCH}_{2}$ & $5-16$ & 8.5 & 7.9 & 0.57 & & & \\
\hline & & $\mathrm{TCH}_{3}$ & $16-40$ & 8.7 & - & 1.16 & \multicolumn{3}{|c|}{ Not studied } \\
\hline & & $\mathrm{TCH}_{4}$ & $40-68$ & 8.6 & 7.9 & 0.19 & & & \\
\hline \multirow{3}{*}{ 38-AK104 } & П17 & RT & $0-21$ & 8.4 & - & 2.57 & 1.13 & 6.7 & 36.0 \\
\hline & П18 & RT & $0-25$ & 8.4 & - & 2.60 & 0.30 & 4.2 & 20.00 \\
\hline & П19 & RT & $0-10$ & 8.2 & - & 2.26 & 4.84 & 12.9 & 32.4 \\
\hline
\end{tabular}

The close to neutral and strong alkaline reactions of the soil solution (indices from 7.1 to 8.6 of $\mathrm{pH}$ units) and the unbalanced content of nutritive substances are typical for the studied soil in humus horizons. The nitrogen content by nitrification capacity and moving phosphorus in upper humus horizons varies from very low to increased level, exchangeable potassium - from very low to very high.

Works [45] study separate questions of morphology and physical-chemical properties of urbanozems of Odessa city that prove the research results of the aforesaid type of anthropogenically 
transformed soils. But for the first time for Odessa city there has been conducted parametrization of the construction, composition and properties of all types and subtypes of soils by elaborated schemes of their classification and cadastral and economic grouping; soil-forming peculiarities have been established. The practical importance of the obtained results provides widening and supplementing theoretical and methodical research bases for soils of different functional-economic zones of human settlements.

It must be noted, that the question of standardization and regulation in the sphere of land protection, namely terms, classification notions and also norms of the quality condition of urban lands in the aspect of functional zoning of territories of a human settlement needs further development.

\section{Conclusions}

Soil formation within human settlements of the steppe zone is determined by both zonal factors and anthropogenic influence, not only because of soil disturbance (construction transformation, inclusions and so on), but also changes of water, thermal and salt regimes, essential for it. The combination of natural and anthropogenic factors of soil formation changes the salt profile, humus composition parameters by profile, composition of absorbed bases and biological properties of soils.

An important motive for choosing a classification principle of human settlement soils is a need in a city planning cadastre. Synchronous profile-genetic and factor-ecologic classification approaches solve not only the problem of profile diagnostics of soils, but also allow grouping of natural, anthropogenically transformed and anthropogenically created (technological) soils depending on functional use of lands. The proposed classification scheme of urbanized territory soils includes both supertype levels and correspondent types and subtypes of soils, connected by the ratio of roles of natural and anthropogenic factors.

Two classes of soils are separated in Odessa city - natural and anthropogenic, and also three groups of types -natural soils, anthropogenically transformed soils and anthropogenically created ones. Soils with a non-disturbed construction within Odessa city are presented by zonal soils of the middle steppe of Ukraine -southern chernozems, weak- or little-humus, that under conditions of wide diversity of water and thermal regimes, organic substance balances have wider diapasons of construction, composition and property parameters.

Anthropogenically transformed soils include two types:

1) urbo-, agrosoils that are surface-transformed ones with a construction, similar to natural. They are divided in subtypes: southern urbochernozems, urbodarkchest soils and so on;

2) urbozems that are deep-transformed soils with the whole profile transformed. It includes subtypes of urbanozems, culturezems, hillozems, recreazems, acephalozems, dumpzems. Anthropogenically created soils are combined in the constructozem type, divided in recultivated soils with an organogenic horizon (technozems), recultivated soils without an organogenic horizon (lithozems), sealed soils (screenzems).

The scheme of supplementing the list of agroproduction soils of Ukraine by the cadastral and economic grouping of soils of urbanized territories is proposed for the city planning cadastre, organization, planning and organization of land management. The grouping includes two combinations:

1) transformed;

2) technological (artificially created) soils - totally 14 cadastral and economic groups.

\section{References}

[1] Aleksandrovskii, A. L., Aleksandrovskaya, E. I., Dolgikh, A. V., Zamotaev, I. V., Kurbatova, A. N. (2015). Soils and cultural layers of ancient cities in the south of European Russia. Eurasian Soil Science, 48 (11), 1171-1181. doi: https://oi.org/10.1134/ s1064229315110022

[2] Vinogradova, S. (2013). The buffer capacity of soils as alkalization ability. Vestnik Baltiyskogo federal'nogo universiteta im. I. Kanta, 1, 102-109.

[3] Smetana, O. M., Marchenko, S. O. (2008). Salt composition of the soil in the residential zone in Krivoy Rog. Pytannia bioindykatsiyi ta ekolohiyi, 13 (1), 161-169. 
[4] Titenko, A. V., Kulik, M. I. (2012). Humus Horizon Of Urban Soils As A Geochemical Barrier In Urban Landscape. Man and Environment. Issues of Neoecology, 1-2, 130-136.

[5] Zharikova, E. A. (2011). Morphology peculiarities and physical properties of the urban soils in Vladivostok. Vestnik KrasGAU, 8, 24-29.

[6] Khokhryakova, A. I. (2016). Soils of the cities: features of genesis, classification, diagnostics. Visnyk Odeskoho natsionalnoho universytetu. Seriya: Heohrafichni ta heolohichni nauky, 21 (1), 110-125.

[7] Lehman, A. (2006). Technosols and other proposals on urban soils for the WRB (World Reference Base for Soil Resources). International Agrophysics, 20, 129-134.

[8] Bullock P., Gregory, P. J. (Eds.) (1991). Soils in the urban environment. John Wiley \& Sons. doi: https://doi.org/10.1002/ 9781444310603

[9] Khokhryakova, A. I. (2020). The content of heavymetals in soils of Odessa city. East European Scientific Journal, 3 (55), 12-23.

[10] Ghadimi, F., Ghomi, M., Ranjbar, M., Hajati, A. (2013). Statistical Analysis of Heavy Metal Contamination in Urban Dusts of Arak, Iran. Iranica Journal of Energy \& Environment, 4 (4), 406-418. doi: https://doi.org/10.5829/idosi.ijee.2013.04.04.13

[11] Khokhryakova, A. I., Kulidzhanov, E. V. (2017). Assessment of soils toxicity of odessa city parks by biotesting. Zbirnyk tsentru naukovykh publikatsiy «Veles» za materialamy mizhnarodnoi naukovo-praktychnoi konferentsiyi 1 chastyna: «vesniani naukovi chytannia». Kyiv: Tsentr naukovykh publikatsiyi, 20-28.

[12] McCrackin, M. L., Harms, T. K., Grimm, N. B., Hall, S. J., Kaye, J. P. (2008). Responses of soil microorganisms to resource availability in urban, desert soils. Biogeochemistry, 87 (2), 143-155. doi: https://doi.org/10.1007/s10533-007-9173-4

[13] Barmin, A. N., Kozyreva, V. N., Zimovets, P. A. (2012). Spatial analysis of soils. Geologiya, geografiya i global'naya energiya, 4 (47), 192-198.

[14] Lee, C., Li, X., Shi, W., Cheung, S., Thornton, I. (2006). Metal contamination in urban, suburban, and country park soils of Hong Kong: A study based on GIS and multivariate statistics. Science of The Total Environment, 356 (1-3), 45-61. doi: https:// doi.org/10.1016/j.scitotenv.2005.03.024

[15] Soil Taxonomy: A basic system of soil classification for making and interpreting soil surveys (1975). US Department of Agriculture. Soil Conservation Service, 436.

[16] Dobrovol'skiy, G. V. (1997). Pochva, gorod, ekologiya. Moscow: Fond «Za ekologicheskuyu gramotnost'», 320.

[17] Ivanyuk, H. (2013). Analysis of "Systematics of Polish Soils". Visnyk of the Lviv University. Series Geography, 44, $122-132$. doi: https://doi.org/10.30970/vgg.2013.44.1210

[18] Kalabekov, A. L. (2003). Problemy ekologii: Ekologicheskiy monitoring v otsenke zagryazneniya gorodskoy sredy. Moscow: IM-Inform, 216.

[19] Collective Morfogeneticky Klasifikancy system pod Slovenska (2000). Bazalna reverencna taxonomia. Bratislava, 76.

[20] Polupan, M. I., Solovei, V. B., Velychko, V. A.; Polupan, M. I. (Ed.) (2005). Klasyfikatsiya gruntiv Ukrainy. Kyiv: Ahrarna nauka, 300.

[21] Tykhonenko, D. H. (2001). Do pytannia pro klasyfikatsiiu gruntiv Ukrainy. Gruntoznavstvo, 1 (1-2), 15-23.

[22] Polupana, N. I. (Ed.) (1988). Pochvy Ukrainy i povyshenie ih plodorodiya. Vol. 1. Ekologiya, rezhimy i protsessy, klassifikatsiya i genetiko-proizvodstvennye aspekty. Kyiv: Urozhay, 296.

[23] Polupan, M. I., Solovei, V. B., Kysil, V. I., Velychko, V. A. (2005). Vyznachnyk ekoloho-henetychnoho statusu ta rodiuchosti gruntiv Ukrainy. Kyiv: Koloobih, 304.

[24] Medvedeva, O. V. (2004). Experience of classification city soils of the steppe zone of Ukraine. Gruntoznavstvo, 5 (1-2), 34-39.

[25] Pro zatverdzhennia Poriadku vedennia Derzhavnoho zemelnoho kadastru: Postanova Kabinetu Ministriv Ukrainy vid 17.10.2012 r. No. 1051 (2012). Ofitsiynyi visnyk Ukrainy, 89, 183.

[26] DSTU ISO 11465-2001. Yakist gruntu. Vyznachennia sukhoi rechovyny ta volohosti za masoiu. Hravimetrychnyi metod (ISO 11465:1993, IDT) (2002). Kyiv: Derzhstandart Ukrainy, 5.

[27] DSTU 4730:2007. Yakist gruntu. Vyznachennia hranulometrychnoho skladu metodom pipetky v modyfikatsiyi N. A. Kachynskoho (2008). Kyiv: Derzhspozhyvstandart Ukrainy, 24.

[28] DSTU 4289:2004. Yakist gruntu. Metody vyznachennia orhanichnoi rechovyny (2005). Kyiv: Derzhspozhyvstandart Ukrainy, 10.

[29] GOST 26951-86. Pochvy. Opredelenie nitratov ionometricheskim metodom (1986). Moscow, 7.

[30] DSTU 8347:2015. Soil Quality. Determination of mobile sulfur in modification of NSC ISSAR named after O. N. Sokolovsky (2017). Kyiv: DP «UkrNDNTs».

[31] DSTU 4114-2002. Grunty. Vyznachennia rukhomykh spoluk Fosforu i Kaliyu za modyfikovanym metodom Machyhina (2002). Kyiv: Derzhstandart Ukrainy, 11. 
[32] DSTU 8346:2015. Soil quality. Methods for determining the conductivity, pH and solid residue of a water extract (2017). Kyiv: $\mathrm{DP}$ «UkrNDNTs».

[33] DSTU ISO 10390:2007. Yakist gruntu. Vyznachennia pH (ISO 10390:2005, IDT) (2009). Kyiv: Derzhspozhyvstandart Ukrainy.

[34] GOST 26487-85. Soils. Determination of exchangeable calcium and exchangeable (mobile) magnesium by CINAO methods (1985). Moscow: Izd-vo standartov, 13.

[35] DSTU 7912:2015. Soil Quality. The method of exchange sodium definition (2015). Kyiv: DP «UkrNDNTs», 9.

[36] DSTU 7943:2015. Soil quality. Carbonates and bicarbonates ions definition in water extract (2016). Kyiv: DP «UkrNDNTs», 9.

[37] DSTU 7908:2015. Soil quality. Chlorine-ion definition in water extract (2016). Kyiv: DP «UkrNDNTs», 13.

[38] DSTU 7909:2015. Soil Quality. Sulfates-ion definition in water extract (2016). Kyiv: DP «UkrNDNTs», 11.

[39] DSTU 7944:2015. Soil Quality. Sodium and kalium ions definition in water extract (2016). Kyiv: DP «UkrNDNTs», 9.

[40] DSTU 7945:2015. Soil Quality. Calcium and magnesium ions definition in water extract (2016). Kyiv: DP «UkrNDNTs», 10.

[41] Stroganova, M. N. (1992). Gorodskie pochvy: opyt izucheniya i sistematiki (na primere yugo-zapadnoy chasti g. Moskvy). Pochvovedenie, 7, 16-24.

[42] Tyutyunnik, Yu. G. (2014). Genesis, diversity and ecology of urban soils (for example the park «Feofania», Kiev). Gruntoznavstvo, 15, 3-4, 64-73.

[43] Tykhonenko, D. G., Gorin, M. O. (2013). To problem of mapping of yrbanozems. Visnyk Kharkivskoho natsionalnoho ahrarnoho universytetu imeni V. V. Dokuchaieva. Seriya: Gruntoznavstvo, ahrokhimiya, zemlerobstvo, lisove hospodarstvo, ekolohiya gruntiv, 2, 5-11.

[44] Khokhriakova, A. I. (2019). Henetychni horyzonty gruntiv urbanizovanykh terytoriy, yikh symvolika ta nomenklatura (na prykladi m. Odesa). Rozvytok ahrarnoi haluzi ta vprovadzhennia naukovykh doslidzhen u vyrobnytstvo: materialy Mizhnar. nauk.-prakt. konf. Mykolaiv, 147-149.

[45] Zelinska, N. Yu. (2001). Do pytannia pro osoblyvosti antropohenno-utvorenykh gruntiv mista Odesy ta yikh systematyky. Visnyk Odeskoho natsionalnoho universytetu. Ser.: Heohrafichni ta heolohichni nauky, 6 (9), 5-9.

Received date 28.07.2020

Accepted date 05.09.2020

Published date 30.09.2020
(C) The Author(s) 2020

This is an open access article under the CC BY license (http://creativecommons.org/licenses/by/4.0). 